of cells with ${ }^{22} \mathrm{Na}$, washed them, and after resuspending the cells in serum measured sodium efflux rate constants while noradrenaline was no longer present. In contrast, we used Ringer-phosphate-bicarbonate-buffer ( $\mathrm{pH} 7 \cdot 6$ ), not serum, and adrenaline or noradrenaline was present while the flux rates were measured. Possibly the serum preparations became more alkaline during the experiment (no evidence was presented), since on standing serum becomes considerably more alkaline within 30 minutes, even at $25^{\circ} \mathrm{C}$. We have shown that pH significantly affects $\mathrm{Na}^{+}$, $\mathrm{K}^{+}$-ATPase activity, ${ }^{9}$ and it is therefore important that flux rates are measured at constant $\mathrm{pH}$ in all experiments. Moreover, $\mathrm{Na}^{+}, \mathrm{K}^{+}$-ATPase activity is affected by changing the concentration of sodium, potassium, and magnesium, and it would be more difficult to ensure the same concentration of all these substances in all experiments if serum (and not buffer) is used. Serum also contains many substances that may affect leucocyte ion flux, alone or in synergism with catecholamines, such as triiodothyronine (Khan and Baron, in preparation).

D N BARON

R J GREEN

F A KHAN

Department of Chemical

Pathology and

Royal Free Hospital School of
Retism,

Medicine

London NW3 2QG

1 Bradlaugh R, Riozzi A, Heagerty AM, Bing RF, Swales JD, Thurston $H$. Inhibition of sodium pump activity by physiological doses of noradrenaline in human leucocytes and rat aortae Clin Sci 1984;67:41.

2 Baron DN, Green RJ, Khan FA. Adrenaline and ion flux in isolated human leucocytes. Clin Sci (in press) Brown MJ, Brown DC, Murphy MB. Hypokalemia from beta $a_{2}$-receptor stimulation by circulating

4 Struthers AD, Reid JL, Whitesmith R, Rodger

Effect of intravenous adrenaline on electrocardiogram, blood pressure and serum potassium. Br Heart $\mathcal{F} 1983 ; 49: 90-3$.

5 Ball SG, Berkin KE, Inglis GC. Hypokalemia from beta 2 -receptor stimulation by epinephrine. $N$ Engl

F Med 1984;310:1330.
6 Motulsky HJ, Insel PA. Adrenergic receptors in man Direct identification, physiological regulation, and

7 Van Zwieten PA, Timmermans PBMW 307:18-29. classification of $\alpha$-adrenoceptors. Research and classification of $\alpha$-adrenocepto
Clinical Forums $1983 ; 5(2): 27-34$.

8 Smith SR, Kendall MJ. Metabolic responses to beta. 190-4.

9 Baron DN, Khan FA. Optimal conditions for measurement of Na,K-ATPase of human leucocytes.

** Dr Riozzi and others reply below.-ED, $B M \mathcal{F}$.

SIR,-We would agree with Professor Baron and colleagues that the apparent discrepancy between the results of their experiments and ours is probably attributable to differences in experimental method. Like them, we cannot produce consistent effects with noradrenaline in the leucocyte using synthetic media. This is true of other cells. For example, exposure of erythrocytes to $8 \mathrm{nM}$ noradrenaline in buffer revealed no effects (ouabain sensitive efflux rate constant $0.14(0.03) v 0.14(0.01) / \mathrm{h}$ with noradrenaline). Repeating the experiments in plasma, however, gave similar findings to our report on leucocytes (ouabain sensitive efflux rate constant $0.2(0.01) v$ $0.16(0.02) / \mathrm{h}$ with noradrenaline; $\mathrm{p}<0.05)$. The results cannot be explained by $\mathrm{pH}$ changes occurring during the incubation period because control experiments were performed simultaneously, and the addition of noradrenaline to plasma did not affect $\mathrm{pH}$ when compared with control without noradrenaline.

It would be surprising to explain our report by an effect of noradrenaline on $\beta_{2}$ adrenoceptors, in view of the much greater affinity of adrenaline for such receptors. ${ }^{1}$ In our studies abolition of noradrenaline-induced inhibition of the sodium pump could be achieved only with a high concentration of propranolol. Nevertheless, catecholamines have been shown to depress the sodium pump in cardiac and aortic muscle,$^{2-4}$ although the mechanism remains to be fully elucidated. These effects are clearly tissue specific, since, as Professor Baron and colleagues point out in other tissues, stimulation of $\mathrm{Na}^{+} \mathrm{K}+\mathrm{ATPase}$ may occur. The fact remains that physiological concentrations of plasma catecholamines appear to influence profoundly leucocyte and erythrocyte sodium transport, two tissues widely studied in experiments on cation handling in hypertension. In view of these findings correct interpretation of such experiments will have to take into account the possible influence of catecholamines.

A Riozzi

A M HEAGERTY

R F BING

STUART BRAND

C R DUNK

H THURSTON

J D Swales

Department of Medicine,

Leicester Royal Infirmary,

1 Brown MJ, Brown DC, Murphy MB. Hypokalaemia from beta ${ }_{2}$-receptor stimulation by circulating epinephrine. N Engl f Med 1983;309:1414-9.

Struthers AD, Davies DL, Harland D, Quigley C, Brown MJ. Adrenaline causes potassium influx in skeletal muscle but potassium

Bradlaugh R, Riozzi A, Heagerty AM, Bing RF, Swales JD, Thurston $H$. Inhibition of sodium RF activity by physiological doses of noradrenaline in human leucocytes and rat aortae. Clin $S c i 1984 ; 67$ : 41 .

Buckler KJ, Bhattacharya SS, Flear CTG. Actions of catecholamines and betablockers on $\mathrm{Na}^{-}$pump activity in heart and skeletal muscle. Clin $S_{c i}$

SIR,-Dr A Riozzi and others reported that noradrenaline inhibits ouabain sensitive sodium efflux from normal leucocytes. As part of a systematic study of the action of various compounds on membrane ion transport we have also examined the effect of some adrenoceptor agonists and antagonists on erythrocyte and leucocyte sodium efflux. In these studies normal red cells were washed and loaded with ${ }^{22} \mathrm{Na}$ under physiological conditions as described elsewhere ${ }^{1}$ and incubated in $0.005 \mathrm{M}$ glycine-imidazole buffer containing $0.15 \mathrm{M}$ saline and one of the following: isoprenaline $(10 \mathrm{nmol} / \mathrm{l})$, noradrenaline (10 and $25 \mathrm{nmol} / \mathrm{l})$, phenylephrine (10 nmol/1), propranolol (1 $\mu \mathrm{mol} / \mathrm{l})$, and both noradrenaline $(10 \mathrm{nmol} / \mathrm{l})$ and propranolol. Sodium efflux was measured as the appearance of radioactivity in the supernatant fluid. First order efflux rate constants for sodium were $0.31 / \mathrm{h}$ for the control sample and $0.31,0.30,0.34,0.32$, 0.35 , and $0.31 / \mathrm{h}$ for samples incubated with the above compounds, respectively. Thus no effect of $\alpha$ or $\beta$ adrenoceptor agonists or blockers on erythrocyte sodium efflux was found.

A corresponding result was obtained in leucocytes prepared similarly to those of $\mathrm{Dr}$ Riozzi and his colleagues, though in this case only the effect of noradrenaline (10 and 100 $\mathrm{nmol} / \mathrm{l}$ ) was studied. Efflux rate constants for the control and noradrenaline containing samples were less than those reported by Dr Riozzi and colleagues but again no effect of noradrenaline was observed. Values obtained were 0.86 (control), 0.85 ( $10 \mathrm{nmol} / 1$ noradrenaline), and $0.81 / \mathrm{h}(100 \mathrm{nmol} / 1$ noradrenaline). The small reduction noted at $100 \mathrm{nmol} / \mathrm{l}$ noradrenaline is unlikely to be of physiological significance. A sample containing ouabain $(1 \mathrm{mmol} / \mathrm{l})$ gave a value of $0.51 / \mathrm{h}$

The possibility raised by the authors that noradrenaline may interact differently with patients' cells and thereby produce or exaggerate abnormal sodium trarsport was studied in a patient with untreated essential hypertension (lying blood pressure 200/107 $\mathrm{mm} \mathrm{Hg}$ ) and one with borderline hypertension $(147 / 87 \mathrm{~mm} \mathrm{Hg}$ ), also untreated. First order rate constants for red cell sodium efflux were 0.31 (control), 0.33 (noradrenaline $10 \mathrm{nmol} / \mathrm{l}$ ) and 0.09 (ouabain $1 \mathrm{mmol} / \mathrm{l}$ ) $/ \mathrm{h}$ respectively in the first patient and $0.33,0.34$, and $0.09 / \mathrm{h}$ in the second.

Our conclusion from these studies, in contrast to that of Dr Riozzi and others, is that noradrenaline has no effect on erythrocyte or leucocyte sodium transport in either normal or hypertensive subjects.

J A Millar P M BRAMLEY

Department of Pharmacology, and Wellcome Medical Research Institute Orago Medical School, New Zealand

1 Millar JA, Bramley PM, Paulin JM, Simpson FO. Evidence against a circulating ouabain-like inhibitor as a cause of increased red cell sodium in essent
hypertension. Fournal of Hypertension (in press.)

\section{Lymphocytes are rhythmic: is this important?}

SIR,-Drs Martin S Knapp and Roy Pownall (17 November, p 1328) highlighted the possible implications of the diurnal variation in $T$ cell subsets in normal subjects. We studied variation in $T$ cell subsets over 12 months in 30 atopic subjects with hay fever.

Subsets were defined using OKT3, OKT4, and OKT8 monoclonal antibodies in July-August 1983, February-April 1984, and July-August 1984 All blood samples were taken between 0900 and 1200 and prepared the same day. Two hundred cells were counted under a microscope using phase contrast and ultraviolet light. The mean OKT4: OKT8 ratios were significantly higher in the summer months (see table) than our laboratory control of $1.41(\mathrm{SD} 0.35)(\mathrm{p}<0.05)$ and this was due to a significantly reduced OKT 8 subset $(p<0.01)$. A reduction in the OKT4:OK $\mathrm{O} 8$ ratio was noted in the winter, due to a significant increase in the OKT8 subset $(\mathrm{p}<0.01)$.

As far as we are aware seasonal variation in the OKT 4:OKT8 ratio has not been described, and its mechanism is obscure. Fc-IgG surface receptors on $\mathrm{T}$ cells, expressing a suppressor population ( $\mathrm{T} \gamma$

Seasonal variation in $T$ cell subsets in hay fever sufferers. Results are mean percentages $(S D)$ of total number of lymphocytes

Summer '83 Winter '84 Summer '84

\begin{tabular}{llll}
\hline OKT3 & $62 \cdot 2(9 \cdot 5)$ & $65 \cdot 7(12 \cdot 8)$ & $61 \cdot 2(12 \cdot 2)$ \\
OKT4 & $43 \cdot 8(9 \cdot 2)$ & $46(9 \cdot 8)$ & $42 \cdot 9(7 \cdot 8)$ \\
OKT8 & $24.7(8.5)^{* *}$ & $31.9(11 \cdot 8)$ & $25 \cdot 1(7)^{* *}$
\end{tabular}

$\begin{array}{lccc}\text { OKT8 } & 24.7(8.5)^{* *} & 31.9(11.8) & 25 \cdot 1(7)^{* *} \\ \text { OKT4:OKT8 } & 1.94(0.81)^{*} & 1.56(0.64) & 1.87(0.67)\end{array}$ ${ }^{*} \mathrm{p}<0 \cdot 05 ;{ }^{* *} \mathrm{p} \quad 0.01$. Significance values comparing
values in summer' 83 and ' 84 with those in winter ' 84 . 
cells), may be lost after exposure to IgG immune complexes, the cells usually converting to FcIgM receptors, which express a helper population (T $\mu$ cells). ${ }^{1}$ Exposure to such immune complexes in the summer may account for the apparent reduction in OKT 8 cells. We might have expected a concomitant increase in helper cells, but this was not observed. Nevertheless, cells characterised by $\mathrm{OKT} 4$ and $\mathrm{OKT} 8$ monoclonal antibodies bear little relation to those characterised by Fc-IgG and Fc-IgM receptors."

We would be cautious in interpreting abnormalities and variation in $T$ cell subsets defined by monoclonal antibodies. Firstly, in organ specific diseases, such as Graves' disease, where abnormalities in subsets have been described, ${ }^{3}$ it is perhaps surprising that gross changes are observed, since $T$ cells are highly antigen specific and any abnormality should affect only a small fraction of the T cell subset. Secondly, the commonly used monoclonal antibodies do not adequately define function -for example, the OKT4 population is known to harbour a group of cells capable of suppressor function."

The conflicting reports of $T$ cell subset abnormalities in hay fever sufferers may be explained by their seasonal nature and serve to emphasise the importance of considering not only the time of day but also, in some diseases, time of year when reporting data using monoclonal antibodies.

A G FENNerty

K P JONES

B H DAVIES

Asthma and Allergy Unit,

Sully Hospital

Penarth, South Glamorgan Cl:6 2YA

1 Pichler W, Lum L, Broder S. Fe receptors on human $T$ lymphocytes. 1. Transition of TY to $T: L$ cells f Immunol 1978;121:1540-8.

2 Reinherz EL, Moretta L, Roper M, et al. Human T lymphocyte subpopulations defined by Fc receptors and monoclonal antibodies. A comparison. I Exp

Ludgate EM, McGregor AM, Weetman AP, et al. Analysis of T cell subsets in Graves disease 1984;288: $526-30$

4 Thomas Y, Rogozinski L, Irigoven $\mathrm{OH}$, et al. Functional analysis of human T cell subsets defined by monuclonal antibodies IV induction of suppressor cells within the OKT4 + population. F Exp Med $1981 ; \mathbf{1 5 4}: 459-67$.

SIR,-The recent leading article by Dr Martin S Knapp and Mr Roy Pownall (17 November, $\mathrm{p}$ 1328) correctly behoves investigators to report not only the discovery of biological rhythms but also their absence. The lack of a rhythm may not only be of fundamental importance but also be of immediate value in that the variable lacking a rhythm can be measured at any time without the possibility of a misleading result due to an unidentified rhythm. This is of particular importance in routine clinical chemistry and immunology tests. If any of these were shown to exhibit notable rhythms then sampling times during clinical trials could be critical. If a given test has not been investigated for rhythmic changes then it would be a wise precaution to take samples at the same time of day throughout a trial. Some biochemical tests used to monitor patients with rheumatoid arthritis have been shown to lack rhythmic changes during "clinic hours," when blood samples are usually taken, hence eliminating circadian variation as a source of error in clinical trials. ${ }^{1}$ This does not, however, eliminate the possibility of biologically important changes during the night in these or other tests, and some clinical features of rheumatoid arthritis, such as grip strength, certainly do show such changes.

Some apparent rhythms may be a consequence of variable factors such as food intake and changes in social habits. These factors might easily give misleading results in studies with only small numbers of subjects. The limitations of accuracy, precision, interobserver and intraobserver variation, and day to day variation of the method used to assess the particular feature under investigation need to be thoroughly elucidated in advance.

Rhythms are often ignored in pharmacokinetic studies, where, for single dose studies, the dose is invariably given at the start of the day so that blood samples can be conveniently collected throughout normal working hours. Studies with indomethacin" and prednisolone ${ }^{3}$ have shown clinically significant variations in kinetic variables in relation to the time of day of drug intake. A recent investigation of ibuprofen in normal volunteers has shown considerable intersubject and intrasubject variation in kinetics when single doses are given at $800 \mathrm{am}, 1200$ noon, $600 \mathrm{pm}$, and 1200 midnight (K E Surrall, unpublished observations). This may have clinical importance-for example, in the more efficient alleviation of early morning stiffness in patients with rheumatoid arthritis. Conversely, rhythms may contribute to drug side effects or, in turn, drugs may affect rhythms, and this then leads to toxic reactions.

Such studies are, however, clearly just the tip of the iceberg in terms of a more efficient application of the available therapeutic armoury, and much more work is needed to make use of recognised biological rhythms.

J S Dixon N G Sitton K E SURrali

Clinical Pharmacology Unit

(Rheumatism Research), Royal Bath Hospital,
Harrogate HG1 2PS

1 Sitton NG, Taggart AJ, Dixon JS, Surrall KE, Bird HA. Circadian variation in biochemical assessments used to monitor rheumatoid arthritis. Ann Rheum Dis $1984 ; 43: 444-50$

2 Reinburg A, Smolensky MH. Circadian changes of drug disposition in man. Clin Pharmacol 1982;7:

3 English J, Dunne M, Marks V. Diurnal variation in prednisolone kinetics. Clin Pharmacol Ther 1983

\section{Certifying death in infancy}

SIR,-The World Health Organisation recommended a modified certificate to record both maternal and infant causes or conditions for early neonatal deaths. Dr Maureen J Scott (1 December, p 1511) argues that the new certificate should be introduced to cover deaths throughout the first year of life. Her table II indicates that $59\left(42^{\circ}{ }_{0}\right)$ out of 140 deaths occurring from 28 days to 1 year were "birth determined."

There appears, however, to be a misunderstanding of the additional information that will be available from this new certificate. Forty three of the 59 deaths were from congenital malformations and it is not clear that any different information would be recorded for these deaths whatever style of certificate were to be used. By requesting maternal and fetal causes, the form may allow additional conditions to be recorded for at least some of the 15 deaths Scott recorded as due to prematurity. The gain in information for deaths from 28 days to 1 year that are due to prematurity has to be balanced against the use of a certificate which would be inappropriate for most of the
Postneonatal deaths by cause in England and Wales in 1982

\begin{tabular}{|c|c|c|c|}
\hline \multirow{3}{*}{$\begin{array}{l}\text { ICD codes } \\
740-759 \\
760-763 \\
773 \\
764-766\end{array}$} & \multirow{2}{*}{$\begin{array}{l}\text { Cause } \\
\text { Congenital malformations } \\
\text { Relating to maternal conditions }\end{array}$} & \multicolumn{2}{|c|}{ No $\left({ }^{\prime \prime}\right)$} \\
\hline & & $\begin{array}{r}542 \\
2\end{array}$ & $\begin{array}{r}(19 \cdot 5) \\
(0 \cdot 1)\end{array}$ \\
\hline & $\begin{array}{l}\text { Relating to gestation and } \\
\text { birth weight }\end{array}$ & 4 & $(0 \cdot 1)$ \\
\hline $\begin{array}{l}767-768 \\
769-772, \\
774-779\end{array}$ & $\begin{array}{l}\text { Relating to the birth } \\
\text { Other perinatal conditions }\end{array}$ & $\begin{array}{l}13 \\
92\end{array}$ & $\begin{array}{l}(0.5) \\
(3 \cdot 3)\end{array}$ \\
\hline $\begin{array}{l}798 \\
140-239 \\
\text { E } 800-\mathrm{E} 999 \\
001-139 \\
240-739 \\
780-797 \\
799\end{array}$ & $\begin{array}{l}\text { Sudden infant death syndrome } \\
\text { Neoplasms } \\
\text { Injury and poisoning } \\
\text { All causes other than above }\end{array}$ & $\begin{array}{r}1066 \\
25 \\
110 \\
919\end{array}$ & $\begin{array}{r}(38 \cdot 4) \\
(0 \cdot 9) \\
(4 \cdot 0) \\
(33 \cdot 1)\end{array}$ \\
\hline & 1 otal & & 00. \\
\hline
\end{tabular}

deaths (about $88^{\circ}$, from the material presented by Dr Scott).

The table shows the underlying cause of death for the 2773 deaths between the ages of 28 days and 1 year that occurred in England and Wales in 1982. This suggests that about $111\left(4_{0}^{\circ}\right)$ might have fetal and maternal conditions recorded as contributing to the cause of death. For the small proportion of deaths after 28 days of life where maternal factors are relevant the diagnoses can be recorded in part II of the traditional death certificate. From 1 January 1985 the Office of Population Censuses and Surveys will be coding all diagnoses recorded on the death certificate; it will then be feasible to produce counts of maternal conditions contributing to death after the neonatal period.

M R ALDERSON BeVERLEy BotTING M MURPHY

Office of Population Censuses and Surveys,
London WC2B 6JP

\section{Consensus development conference: coronary artery bypass grafting}

SIR,-Your publishing the report of this consensus meeting so quickly and the tone of your leader both implied approval of such deliberations (1 December, pp 1477, 1527). Surely it is ridiculous to expect that starting from scratch, or possibly from preconceived prejudices, two experts with 10 laymen (four of whom were medically qualified) should arrive at correct conclusions about so complicated a subject as this. The data presented by the "experts" were incomplete and contradictory and from the audience often irrelevant and emotional.

The reasonableness of the final report does not nullify the stupidity of the concept. It was probably a tribute to the cardiologist and cardiac surgeon, who must have directed the "jury" well, including introducing material which had not been given in the open meeting.

The problem of such a gathering is that with the names of the King's Fund and the $B M \mathcal{F}$ backing it, conclusions are liable to be thought to be weightier than is the case, just as the debate in the Oxford Union about not fighting for King and country misled German thinking before the war, so such trials of debating skills could produce conclusions which are hopelessly wrong and should not be thought to carry any authoritative message. The $B M Y$ should think carefully before lending its weight to any further entertainment of this sort.

Harefield Hospital,
Uxbridge, Middlesex UB9 6JH

R B PRIDIE 